УДК 378.147

DOI:

Юлія Колісник-Гуменюк, кандидат педагогічних наук, старший викладач ВСП “Львівський навчально-науковий иентр професійно-технічної освіти” Національного педагогічного університету імені М.П. Драгоманова, м. Київ

\title{
КРЕАТИВНІСТЬ ЯК ПРОЦЕС ТВОРЧОСТІ, САМОВИРАЖЕННЯ ТА САМОСТВЕРДЖЕННЯ ОСОБИСТОСТІ
}

Говорячи про креативність людини, передусім мають на увазі творчу особистість, яка нестандартно й оригінально мислить, має гнучкий розум, широку обізнаність, самостійність, спроможсу знаходити вихід з безвихідних ситуачій. Дана категорія є ключовим аспектом підготовки викладачів до вирішення завдань модернізаиії освіти, адже відмова від звичних стереотипів відтворення застарілих і неефективних прийомів педагогічної діяльності застосування інновацій, передусім передових технологій, під час навчання у педагогічних 3 ВО сприяє формуванню конкурентоздатних викладачів, озброєних необхідними компетентностями. Тому ми спробували розкрити та проаналізувати дане поняття.

Ключові слова: креативність; митець; викладач; структура; творчість.

Jim. 9.

Yuliya Kolisnyk-Humenyuk, Ph.D.(Pedagogy), Senior Lecturer SSU "Lviv Educational and Scientific Center of Vocational Education" Mykhaylo Drahomanov National Pedagogical University

\section{CREATIVENESS AS A PROCESS OF CREATIVITY, SELF-EXPRESSION AND SELF- APPROVAL OF PERSONALITY}

The key to the successful reform of the Ukrainian educational sector is: to increase access to education; feasibility of educational innovations; ensuring high efficiency of using the resources of the education system; expediency and effectiveness of managerial decisions related to educational policy; publicity; continuity of reforms in the education system; taking into account the interests of training subjects. According to the new paradigm of education, the modernization of teacher training requires: the formation of a modern outlook of future teachers; formation of methodological culture of students as a system of socially-tested principles and methods of organizing theoretical and practical activities; the formation of proper professional and moral qualities of the teacher, etc. The training of teachers of professional and artistic disciplines aims not only to create a system of knowledge, skills, development of personal qualities that meet the requirements of future professional activities, but also the development of the person himself, which involves his participation in the system of humanistic, universal human values.

Taking into account the exceptional importance of harmonization of the clarification of the conceptual apparatus at the present stage of the development of pedagogical science, we have specified the pedagogical category of the most important in the area of improving the training of teachers of professional and artistic disciplines, namely: creativity. Speaking about human creativity, first and foremost means a creative personality that is unconventional and original thinking, has a flexible mind, broad awareness, independence, able to find a way out of hopeless situations.

This category is a key aspect of training teachers to solve the problems of modernization of education, since the abandonment of the usual stereotypes of reproduction of outdated and ineffective methods of pedagogical activity of applying innovations, especially advanced technologies, during training in pedagogical institutions, contributes to the formation of competitive teachers equipped with the necessary competencies.

Keywords: creativity; an artist; a teacher; a structure; creativity.

П остановка проблеми. Основою для самоактуалізації та самореалізації творчої особистості виступає їі креативність. 3 креативністю пов'язаний і розвиток самосвідомості людини, що впливає на оцінку власних досягнень та планування напрямків подальшого самовдосконалення.

Поміж учених різних наукових галузей досі точаться дискусії щодо усвідомлення тотожності чи різниці у визначенні сутності понять “креативний” i “творчий” та їхнього використання у науково-понятійному апараті. Це пов'язано 3 неоднозначним перекладом слів “creatura” (лат.) - “творення", "сrео" (лат.) - "творити”; "creare" (італ.) - “творити”, “creative” (італ.) - “творчий”; “creative” (англ.) - “творчий”, “create” (англ.) “творити, втілювати” тощо [3, 36]. Як правило, обидва поняття збігаються одне з одним та часто використовуються як синоніми.

Мета статті. Проаналізувати складність поняття у різних аспектах: як процес, як продукт, як якості особистості, як середовище (сферу, 


\section{КРЕАТИВНІСТЬ ЯК ПРОЦЕС ТВОРЧОСТІ, САМОВИРАЖЕННЯ ТАСАМОСТВЕРДЖЕННЯ ОСОБИСТОСТІ}

структуру, соціальний контекст, які формують вимоги до твору), як проблему, що підлягає вирішенню.

Виклад основного матеріалу дослідження. Говорячи про креативність людини, передусім мають на увазі творчу особистість, яка нестандартно й оригінально мислить, має гнучкий розум, широку обізнаність, самостійність, спроможну знаходити вихід з безвихідних ситуацій. Термін “креативність" - (від лат. створення, творіння) виражає здатність до осягнення інновацій, трансформації їх до конкретної педагогічної ситуації, спроможність створення інновацій у процесі фахової діяльності. Креативність - це сукупність властивостей психіки, які забезпечують продуктивні перетворення в діяльності особистості. Вона розвивається в процесі діяльності, з'єднується 3 ії провідними мотивами, виявляється як прагнення до процесу творчості, самовираження та самоствердження особистості. Креативний компонент пов'язаний із розвитком пізнавальної активності майбутніх викладачів професійнохудожніх дисциплін, їх самостійності в художньотворчій діяльності, що сприяє формуванню емпатійності, гнучкості, творчої активності, та грунтується на індивідуально-особистісному підході до осягнення індивідуального стилю в професійній діяльності.

Поняття “креативність” у контексті психологічного знання набуло значення до початку 50-х років XX ст. Дж. Гілфорд визначав, що “креативність - це процес дивергентного мислення" та ототожнив поняття креативності і творчого мислення. Однак він включав до структури креативності не лише дивергентність мислення, а й здатність до перетворень, точність розв'язку та інші інтелектуальні параметри. На особливу увагу заслуговують параметри креативності Дж. Гілфорда: здатність до виявлення й формулювання проблем; спроможність до генерування великої кількості ідей; гнучкість мислення; оригінальність мислення; здатність вдосконалювати сприйнятий об'єкт; здатність розв' язувати проблеми шляхом реалізації відповідних аналітико-синтетичних ситуацій [9]. Таким чином, він виділив провідний аспект у креативності- креативне мислення, що характеризується створенням суб' єктивно нового продукту та новоугвореннями в самій пізнавальній діяльності.

Нині існує більше ста означень креативності. Згідно з концепціями креативності Дж. Гілфорда (1969), Е. Торренса (1962), Д. Богоявленської (1983), креативність є загальною характеристикою особистості і впливає на творчу продуктивність незалежно від сфери прояву особистісної активності.

Визначаючи креативність А. Маслоу вважав, що це поняття - це прагнення до творчості, неодмінним атрибутом самоактуалізації, котру можна називати творчим ставленням до життя [5, 298]. На наш погляд, поняття “креативний” і “творчий”, маючи спільну сутнісну основу, все ж відрізняються. Поняття “креативний” можна вважати дещо об'ємнішим за “творчий”. Це зумовлено широтою сфери творчого мислення, різноманітністю форм актуалізації творчого потенціалу особистості та рівнем сформованості мотивації відносно творчої діяльності. Останнім часом все частіше учені наголошують на тому, що XXI ст. слід називати століттям повнопівкульного (або творчого) мислення, коли наявним $€$ феномен гармонійного розвитку та взаємодії правої та лівої півкуль головного мозку. Деякі 3 них стверджують, що саме повнопівкульне мислення $є$ важливим чинником прояву творчого розвитку особистості, експериментально доводячи, що “у процесі активізації взаємодії лівої та правої півкуль мозку синергетично виробляється нова інформація, котра набуває ще більшої інтелектуальної і творчої потужності” [6, 29].

Розділяємо думку Б. Ананьєва, який вважає, що креативність дозволяє ефективно використовувати наявні в арсеналі викладача знання, вміння та навички в нових непередбачених ситуаціях для вирішення нестандартних педагогічних завдань $[1,137]$. Завдяки креативності викладач вибудовує нові засоби взаємодії із студентами, відкриває нові для себе грані цього процесу. У психолого-педагогічній науці під креативністю розуміють здатність суб'єкта до творчості, до конструктивного та нестандартного вирішення педагогічних завдань, а також до усвідомлення власного досвіду.

Як слушно зауважує О. Куцевол, креативність індивіда визначається багатьма чинниками: потребами й запитами суспільства; конкретними економічними та соціальними умовами; загальним обсягом знань і досягнень у певній галузі діяльності; можливостями людської свідомості; біологічними і психологічними особливостями конкретного суб' єкта; його інтелектуальними здібностями, рівнем знань і життєвим досвідом; особистісними рисами тощо [4]. У такий спосіб вона виступає джерелом активності відпрацювання власних переконань і цінностей.

Опрацювання філософської та психологопедагогічної літератури підтверджує припущення стосовно характерних особистісних якостей, 
притаманних творчим, обдарованим людям, яких також можна назвати і креативними. Серед них виокремимо такі: цікавість (жага новизни, інтелектуальна стимуляція, що поступово переростає в пізнавальні інтереси); підвищене відчуття проблем (спроможність дивуватися та бачити проблеми й протиріччя, коли іншим все здається ясним і зрозумілим); надситуативна активність (прагнення до постійного “занурення” у проблему, здібності до “ситуативно нестимульованої діяльності”); високий рівень розвитку логічного мислення (здатність діяти у відповідності 3 вимогами законів логіки); оригінальність мислення (спроможність генерувати нові ідеї та нетрадиційні рішення); гнучкість мислення (здатність швидко та легко знаходити нові стратегії рішень, встановлювати асоціативні зв'язки); підвищений інтерес до розв'язання поставленої проблеми; продуктивність мислення (спроможність до генерування значної кількості незвичайних ідей); легкість щодо асоціювання (уміння знаходити аналогії там, де традиційно вони неможливі); здібності до прогнозування (якості, котра поєднує у собі уяву, інтуїцію, аналітичність); оцінні здібності (навички сприймання, оцінювання та критичного мислення); різнобічність потреб та інтересів (широта та стійке усвідомлення визначених інтересів і потреб); перфекціонізм (прагнення виконувати все щонайкраще); самостійність (незалежність суджень та дій, відповідальність, внугрішня впевненість у правильності поведінки); прагнення до самоактуалізації (прагнення розкрити свій внутрішній потенціал); лідерство (нахили щодо керівництва та організації групової або колективної діяльності); підвищена емоційність (здібність інтуїтивно встановлювати причиннонаслідкові зв'язки та співпереживати); творче сприйняття випадковостей (уміння знаходити користь у непередбачуваних обставинах).

Аналіз сучасних наукових праць дає змогу визначити такі особистісні якості фахівців художніх спеціальностей, пов' язані з креативністю: 1) прагнення до пізнання;2) уміння використовувати досвід інших; 3) спроможність бачити сутність явищ; 4) уміння узагальнювати та аналізувати сприйняте; 5) оригінальність мислення; 6) наявність антиципації (передбачення); 7) розкріпачення підсвідомості; 8) використання нових, нерідко незвичайних асоціацій; 9) здібності до творчих перетворень; 10) уміння інтегруватися з власним витвором; 11) імпровізування у процесі самовираження [3, 36-38].

Характерним для креативної особистості, $\epsilon$ відкритість до нового досвіду, тобто дивергентне мислення, коли пошук відбувається одночасно за різними напрямами, не підпорядковуючись єдиній логіці (на відміну від конвергентного, коли зусилля спрямовуються на відшукання одного, єдиного правильного розв'язку).

Креативність також може бути визначена як процес створення будь-чого, що є як оригінальним, так і таким, що має цінність або характеризується неповторністю, експресивністю та винахідливістю [8]. Креативність - це здатність адаптивно реагувати на необхідність нових підходів і нових продуктів. Така здатність дозволяє також усвідомлювати нове в бутті, хоча процес може мати як свідомий, так і несвідомий характер.

Стосовно педагогічної діяльності, О. Антонова тлумачить креативність як здатність викладача до “'творчого пошуку, нестандартного розв'язання педагогічних задач...”, що характеризується швидкістю (продуктивністю) і гнучкістю думки, оригінальністю, допитливістю, точністю і сміливістю $[2,16]$. Д. Чернілевський і О. Морозов вважають креативність особливою стійкою індивідуальною властивістю, яка зумовлює здатність виявляти соціально значущу творчу активність [7, 21].

Науковці пропонують таку структуру креативності: інтерес до парадоксів; схильність до сумнівів; почуття новизни; гострота думки; творча уява; інтуїція; естетичне почуття краси; дотепність; здатність відкривати аналогії; сміливість і незалежність суджень; самокритичність; логічна суворість; здатність користуватися різними формами доказів та ін. Умовами прояву креативності $€$ наявність: творчої особистості, творчого процесу та творчого середовища. Для розвитку креативності, що здійснюється за логікою цілеспрямованого руху від наслідування до власної творчості, необхідно створити відповідні умови: нерегламентоване середовище, демократичні відносини, належну мотивацію, високий рівень професіоналізму викладача.

Висновки. У цьому контексті згадаємо, що вимогами Болонського процесу є забезпечення якості професійної підготовки студентів у ЗВО. У професійній освіті пріоритетним завданням визначається формування компетенцій i створення інформаційно-освітнього середовища, де б творчі та креативні люди могли реалізувати свої можливості та навички. Адже креативність $\epsilon$ властивістю не пізнавальних процесів, а найвищих можливостей людини для повноцінної самореалізації в усіх сферах іiї життєдіяльності, серед яких професійну сферу більшість вчених визначають як провідну для самореалізації особистості. Реалізація творчого потенціалу пов'язана $з$ механізмами внутрішньої активності особистості, продуктивністю пізнавальних 


\title{
КРЕАТИВНІСТЬ ЯК ПРОЦЕС ТВОРЧОСТІ, САМОВИРАЖЕННЯТАСАМОСТВЕРДЖЕННЯ ОСОБИСТОСТІ
}

процесів і проявами креативності. Від творчого потенціалу залежить рівень креативної самореалізації. Тому гармонійний розвиток особистості й продуктивність професійної діяльності пов'язані з проблемою гармонійної й творчої цілісності, суб'єктивного й об'єктивного формування образу професіонала.

\section{ЛІТЕРАТУРА}

1. Ананьев Б.Г. Человек как предмет познания. Санкт Петербург, 2002. 228 с.

2. Антонова О.С. Педагогічна креативність у структурі педагогічної обдарованості вчителя. Нові технології навчання : наук.-метод. зб.: у 2-х ч. Київ-Вінниця, 2011. Вип. 69., Ч. 2. С. 11-17.

3. Коновець С. Проблеми творчого розвитку майбутніх учителів образотворчого мистецтва. Професійно-художня освіта України: зб. наук. праць / Редкол.: І.А. Зязюн (голова), В.О. Радкевич, Н.М. Чепурна(заступники голови) та ін. Київ; Черкаси, 2007. Вип. IV. С. 34-42.

4. Куцевол О. М. Роль креативного середовища у формуванні творчої особистості в її онтогенезі. Креативна педагогіка: наук.-метод. зб. Вінниця, 2010. Вип. 1. С. 63-68.

5. Маслоу А. Психология бытия. Москва, 1997. 304 с.

6. Бьюзен Тони. Могущество творческого интеллекта. Минск, 2004. 160 с.

7. Чернилевский Д. В., Морозов А.В. Креативная педагогика и психология : учеб. пособ. Москва, $2001.301 \mathrm{c}$.

8. Barron F., Harrington D. Creativity, intelligence and personality. Ann. Rev. of Psychol. 1981. Vol. 32. pp. 439-476.

9. Guilford J. P. Traits of Creativity, in: Creativity / ed. P.E. Vernon. Harmondsworth, 1970. pp. 167188.

\section{REFERENCES}

1. Ananiev, B.G. (2002). Chelovyek kak pryedmyet poznaniya [Man as a subject of cognition]. St.Petersburg, 228 p. [in Russian].

2. Antonova, O.Ye. (2011). Pedahohichna kreatyvnist u strukturi pedagogichnoyi obdarovanosti vchytelia. Novi tekhnolohiyi navchannia: nauk.-metod.zbirnyk, $u$ 2-kh chastynakh [Pedagogical creativity in the structure of pedagogical talent of teacher. New technologies of training: scient.-method.collection in 2 volumes]. KyivVinnytsia, Issue. 69. Part 2, pp. 11-17. [in Ukrainian].

3. Konovets, S. (2007). Problemy tvorchoho rozvytku maibutnikh uchyteliv obrazotvorchoho mystetstva. Profesiyno-khudozhnia osvita Ukrayiny: zb.nauk.prats[Problems of creative development of future teachers of Arts. Professionally-artistic education of Ukraine: coll.of scient. works]. (Eds.). I.A. Ziaziun, V.O. Radkevych, N.M. Chepurna et al. Kyiv, Cherkasy. Issue IV, pp. 34-42. [in Ukrainian].

4. Kutsevol, O.M. (2010). Rol kreatyvnoho seredovyshcha u formuvanni tvorchoyi osobystosti v yiyi ontogenezi. Kreatyvna pedagogika: nauk.metod.zb. [The role of the creative environment in the formation of a creative personality in its ontogenesis. Creative pedagogy: sciant.-method.coll.]. Vinnytsia, Issue 1, pp. 63-68. [in Ukrainian].

5. Maslow, A.(1997). Psilhologiya bytiya [Psychology of Being]. Moscov, 304 p. [in Russian].

6. Buzan Tony (2004). Mogushchestvo tvorcheskogo intellekta [The power of creative intelligence]. Minsk, 160 p. [in Russian].

7. Chernilevskyy, D.V. \& Morozov, A.V. (2001). Kreativnaya pedagogika $i$ psikhologiya: uchebn.posobiye [Creative pedagogy and psychology: a textbook]. Moscov, 301 p. [in Russian]

8. Barron, F. \& Harrington, D. (1981). Creativity, intelligence and personality. Ann. Rev. of Psychol. Vol. 32,pp. 439-476. [in English].

9. Guilford, J. P. (1970). Traits of Creativity, in: Creativity. Ed. P.E. Vernon. Harmondsworth, pp. 167-188. [in English].

Стаття надійшла до редакції 10.05.2019

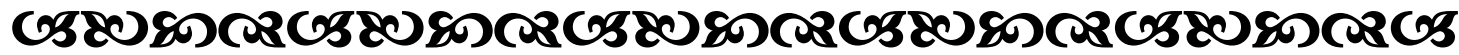

\author{
“Якбайқа, так $і$ життя иінується не за довжину, а за зміст".
}

Ауиій Анней Сенека

давньоримський ббілособ

"Кожна людина - відображення свого внутрішнъого світу. Яћлюдина мислить, такий він $i \in$ в житті".

МаркТТуллій Iூичерон

давньоримський білособ, оратор

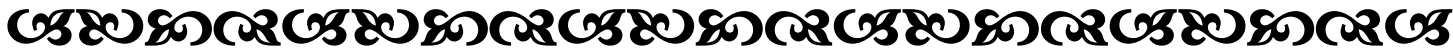

